Філіпенко О. I., викладач кафедри українознавства та лінгводидактики Одеська національна академія харчових технологій

\title{
СИМВОЛІЧНА МЕТРОЛОГІЯ У РОМАНІ-ТЕТРАЛОГІї «ДІТИ ЧУМАЦЬКОГО ШЛЯХУ» ДОКІї ГУМЕННОї
}

У статті досліджено наскільки Докії Гуменній вдалося передати параметри тих явищ (почуттів, уявлень, відчуттів, здібностей...), які неможливо виміряти конкретними мірками, оскільки людство ще не винайшло одиниць вимірювання, стандартів та еталонів для них, але символічні виміри тих явищ наявні у творчості письменниці.

Ключові слова: мірність світу, шкала виміру, духовність, талант, здібності, почуття, кохання.

В статье исследовано насколько Докии Гуменной удалось передать параметры тех явлений (чувств, представлений, ощущений, способностей...), которые невозможно измерить конкретными мерками, поскольку человечество ещуе не изобрело единици змерения, стандартов и эталонов для них, но символические измерения тех явлений имеющиеся в творчестве писательницы.

Ключевые слова: мерность мира, шкала измерения, духовность, талант, способности, чувства, любовь.

The article investigates how Dokiya Humenna has managed to describe the parameters of those phenomena (feelings, ideas, experiences, abilities...) that can not be measured by concrete measures, because humanity has not invented the units of measurements for them yet. It has not developed standards and samples, but they (those phenomena) exist and influence people's lives. Sometimes they decide their fate, decorate or discolor the world, and therefor humanity must pay attention to them and recon with their presence in this world and their dimensions, even if peculiar ones, that are based on the feeling and experiences, that is, symbol icones.

Keywords: dimensionality of the world, scale of measurement, spirituality, talent, ability, feeling, love.

Мірність світу цікавила людство здавна. Виміри простору і часу до цих пір є актуальною проблемою фундаментальних наук. Про різновимірність буття у світі написано багато наукових та філософських праць. У літературознавстві філологічну версію мірності світу у поезії ХX століття досліджувала Ганна Віват [Віват 2013].

Спостереження за світом i різновимірність предметів у ньому детермінували такі загальнопорівняльні характеристики: велике-мале (дрібне, мізерне), довге - коротке, широке - вузьке, глибоке - мілке, товсте - тонке, легке - важке, один - багато, багато - мало. Пізніше людство почало застосовувати числову систему та різні системи виміру простору, часу, маси й об’єму предметів та їхньої кількості. У світі існує кілька систем одиниць виміру, зокрема міжнародна система одиниць (CI), що являє собою набір 
стандартів, у якому створюються одиниці виміру, однак до сьогодні існують речі, які виміряти точно людство ще не навчилося, а відтак маємо особистісні виміри, тобто кожна особистість міряє світ і буття в ньому за своїм розумінням, переконаннями й відчуттями. Не маємо, скажімо, стандартів (шкали) до виміру добра і зла, любові й ненависті, духовної величі й бездуховності, розумової витонченості і грубості, щедрості і скупості, щирості й підступності, правдивості й брехливості, простоти й хитрощів тощо. Не можемо також зафіксувати через певні одиниці виміру здібності, талановитість, геніальність, емоційність. I все ж людство намагається дати оцінку таким явищам, хоч їхні виміри, можна вважати дещо символічними і зафіксувати їх можна лише в контексті тої чи тої ситуації, у порівнянні, співставленні або протиставленні.

Метою цієї роботи є дослідження символічної шкали вимірів нематеріальних речей: явищ, почуттів, обставин на матеріалі творчості Докії Гуменної.

Так, у сюжетній канві роману «Діти Чумацького Шляху» Докії Гуменної наявні різні виміри: просторові, часові, речовинні, грошові тощо. За допомогою різних мір тут визначається заможність, а відтак суспільний статус особистості. Заможність в основному міряється кількістю земельних ресурсів, які $є$ в володінні родини: «Якось аж жалко стало Меркурієві. Скільки на иій землі жилося, скільки чинилося, скільки битв було за изю землю. А от вони орють, сіють і думають, щуо життя лише з ними почалося, ними закінчиться. Батько з усіх усюд стягає землю, міняе щзось на щзось... А скільки людині тої землі треба?» [Гуменна 1998:28].

Або: «Яриней Саргола намагався заволодіти увагою, все починав:

- Oй, свате! Серцее! Я - з мургочки! Було в мого батька семеро синів $і$ сім моргів поля...» [Гуменна 1998:55].

Не останнє місце у людському суспільстві посідали й гроші, котрі здобувалися важкою працею і витрачалися 3 великою обачністю, як про це мовиться у романі Докії Гуменної: «Тепер - як повинитися перед стариими? На Осташенковому хуторі купівля нових черевиків була величезною подією, 
вона траплялася на кілька років раз. Там копійка була он яка дорога» [Гуменна 1998:11].

А ось полілоги між Яринеєм Сарголою та його дітьми (дочками Мокриною та Христею) вказують на те, що через кількість матеріального (землі та грошей) можна зафіксувати й виміри внутрішнього світу людей, означуючи шкалу духовності членів цієї родини:

« - Казав мені вчитель, щзо Павло на інженера вивчиться... Мости залізничні будуватиме.

- E, то тра вчити! - переконано каже дід.

- Ну, а звідки? 3 трьох десятин поля? 3 того півморга, щуо ви мені дали?

- А я звідки брав? Я - з мургочки!.. Що в мене було? Помер ваш дід, а мій тато та й щзо зоставив? Сім моргів поля та й нас, семеро синів...

$<\ldots>$

- Я з мургочки! Отак і ви, діти, не ждіть від мене, робіть та дбайте, то й ви матимете... Хто мені дав?».

$<\ldots>$

- Знать нічого не знаю! - стукотіла вона не раз до діда кулаком по столі, а як не було стола близько, то кулаком об кулак. - Мені моє мусите дати $i$ край! Мені сина треба вивчити!

$<\ldots>$

- Чом он Христя ніколи не допоминається? - кивнув він головою на другу дочку. - А ти все у вічі скачеш, мов присок. Христе, ой, ти в мене дорога дитина, робітницяя!..

- Я недобра, бо цзвікаю, - вставила Мокрина.

- Мені й так добре, - обзивається Христя $і$ изе саме промовляють ї̈ карі відкриті очі, широке чоло з початком проділя вже далі закритим майстерно виложеними складками квітчастої червоної хустки.

- Он Христя й разу ніколи не закинула, щуо тато ї̈ скривдив, а я ї̈ ще й того не дав, щзо й тобі. 
- А нехай собі, я тим не здобрію, - відмахувалася Христя. 3 мене досить того, щзо маю!

I справді, від неї віяло такою повнотою, щэо тільки віддавати» [Гуменна 1998:75-76].

Таких порівняльних характеристичних вимірів у творах Докії Гуменної багато. Письменниця не романтизує й не ідеалізує життя своїх земляків, а показує його в усій повноті і багатогранності, змальовуючи як позитивні, так i негативні боки їхнього буттєвого простору. Духовні виміри посідають вагоме місце у цих буттєвих реаліях. Герої іï творів часто задумуються над сенсом життя, над тими проблемами, що не мають шкали вимірювання, однак без них людське суспільство розвиватися не змогло б. Цим людям притаманні всі людські бажання й поривання. Відомі їм і пристрасть до наживи, скуповування землі, здобутої, щоправда, важкою працею, але й притаманні «втома серия, $i$ потреба чогось кращчого, вищуого, світлішого» [Сорока 2003:49]. Так, одна 3 героїнь роману «Діти Чумацького Шляху», живучи одноманітним хуторським життям, заповненим щоденною важкою працею, задумується над сенсом свого існування й прагне все ж чогось небуденного, високого, незвичайного: «Там цุіпи молотять - гуn-гуn! - по золоті снопів. Там віють, там млинкують, там коноплі тіпають, там соняшники вибивають, солять, иаткують, сушать...

А все ж, відійила напруга, - знов легкий прозорий серпанок смутку, як степові далі, окутує душу. Чогось хочеться, за чимось жаль. Дарочка чогось жде - небувалого, небуденного. Життя на хуторі таке одноманітне - день на день схожий. Якби розказати про ї̈ життя - нема чого розказувати. Роблять, щุоб їсти, їдять, щуоб робити.

A намзо изе все?

$<\ldots>$

Тут, у полях, лише з Богом, Дарка вірила, щзо якась незвичайна доля чекає iï. I то не в заміжжі. Вона відчула повів великого над собою. Недарма їй хочеться чогось такого незвичайного, небуденного» [Гуменна 1998:37;50]. 
Вимірами людського й звіриного в людині переймається інший герой роману й намагається дати оцінку буттєвим клопотам людей i впливові тих життєвих обставин на їхню свідомість та духовність («людяність»): «Та й варт икодувати за старим світом? - думав Тарас. - В изій гонитві за багатством, за маєтностями люди гублять людську подобу, звироднюють до потворного свою психіку, гублять людяність. I хто? Дядько Никодим, який на макове зерно не скористався з чужої праџі, який своӥми мозолями добивався свого уявного добробуту!» [Гуменна 1998:233].

Мірилом людського життя в романі виступає також горілка. Крім фіксованих вимірів алкогольних напоїв, які існували на той час в Україні (восьмушка, бляшанка, сотка, шкалик, п’ятирик, літирка, півока, око, кварта, великий літр, відро, антал тощо), горілкою можна було виміряти ще й людські стосунки, почуття, родинність та й саме життя. Так, у одному випадку кількість випитої горілки вказує на приємне застілля, ступінь довіри до співбесідників, теплоту їхніх почуттів, душевну відкритість. Як-от: «Нечипір Олевський не цурався старих звичаїв, старих друзяк. Ось зустрінеться на ярмарку в Дрижиполі у четвер із Сарголою, Полішуком, Барабашем та іншими хазяями $з$ Троянівських хуторів та й залюбки з ними роздушить півока десь під возом на землі. Спочатку про молодече чумакування згадають, про предків чумаків 3 діда-прадіда, а потім і затягнуть чумаџької.. любили, хвалити Бога, чарку, а бесіда сама текла» [Гуменна 1998:19].

Або: «Випивали вже котрого п'ятирика. Сіли роздушити лише одного, але щзодалі, то більша розбирала охота хазяїв. Вже не одно гаряче принесене було сюди, не одна свіжа пляшка. Від випитого всі поробилися говіркіші, просто незносно балакучі. Приказки, приповідки, примовки, баєчки так $i$ сипалися. Тут були самі куми й свати» [Гуменна 1998:54].

А в іншому випадку горілка стала мірилом долі людської, iï занапащеності: «Щоб він йому запавсятой шинок! <..> Чи воно їй усе те потрібне, чи снилося коли, щзо отаку ганьбу прийдеться пережити? 
I все через оту кляту горілку! Сотки, шкалики, п'ятирики, половинчики, ока, півока наробили» [Гуменна 1998:70].

Для вимірювання сили кохання людство також ще не винайшло вимірювальних одиниць, еталонів чи шкали. Однак одна 3 героїнь роману змогла виміряти силу свого кохання й дати оцінку почуттям коханого, що й вирішило їхню долю, визначило життєві пріоритети: « - Hy, певно, - думалося їи, - Ярина багатша, вона має n’ять десятин приданого. А Петро такий обачний...

А навіщзо ж він зводив ї̈? Нащуо ті ночі сріблясті були, ті поцуілунки жагучі, нестямні? Щоб заронити в ї̈ сериее отруту кохання - тоді розмірковувати, як у житті вигідніше повестися?

Але то велике нещзастя впало на неї, як вона любить його більще, ніж він $\dddot{i i !} \gg$ $<\ldots>$

Що зробити із серцем? Вже на перегній для дітей пішло життя, а серие щуе чогось хоче. Незаймана щуе ичарина порожніла в сериі $і$ хоч проходив ніби нормально циикл життя, вона зоставалася незаповненою. Кожне знаходить собі щуось у житті, чимось запалюеться, кипить пристрастю. А вона? Колись один чоловік відкрив їй глибину ї̈ пристрастів, аж вона сама вжахнулася своєї безодні» [Гуменна 1998:50, 67].

Як можемо переконатися, без одиниць та шкали виміру Докії Гуменній вдалося визначити глибину й щирість кохання своєї героїні. У порівнянні з ним почуття чоловіка, який запалив це незгасне вогнище, здаються занадто приземленими, поміркованими i нівелюються до нуля. Виміри почуттів зафіксовано авторкою 3 високою точністю, описано 3 великим розумінням ситуації. Їх можна порівняти зі шкалою виміру кохання героїні роману в віршах «Маруся Чурай» Ліни Костенко, що теж подані в порівнянні і вказують на певну шкалу виміру, хоч і символічну:

Моя любов чолом сягала неба,

а Грищуь ходив ногами по землі [Костенко 1999:42]. 
Так тонко відчувати, влучно сформулювати й передати через слово трагедію людської душі, зневаженого й розтоптаного закоханого серця, на нашу думку, може лише жінка, яка знається на секретах людської психіки, розуміється на силі людських почуттів і міряє їх душею без всяких мірних одиниць та еталонів.

Удалося Докії Гуменній словесно передати виміри й таланту людського, хоч на таке явище також не існує в сучасній науці ні одиниць вимірів, ні еталонів, ні шкали: «Хитро підморгнувщи, Меркурій торкнувся устами сопілки.

Забреніла ніжна, тендітна мелодія. Це навіть не була музика, а ї̈ дихання. Простесенькі пісеньки Дрижиполя під пальцяям Меркурія ставали граціозними метеликами, щзо пурхали й кружляли в повітрі. Замріяна поліська змінялася грайливою танковою, відзігорна танцюриста - чабанською. <...> Один музичний перехід - $i$ духовим очам являлося наӥвне сільське вуличне гульбище. <..> Ще один поворот, - $i$ вже чується мрійне джеркотання лісового підземного ручая...

Хрисанф сперся ліктем на фортепіано, підпер підборіддя $i$ так непорушно сидів.

Щоб із цүіє̈̈ пищалки могла людина витягти такі чисті, ніжні, своєрідної краси звуки, з такою силою навіяння? Чи цуе він простесенький дитячий інструмент довів до такої високої досконалості, щуо передає нам усю Украӥну!..

Хрисанф чув повів великого таланту від изього кострубатого, неоковирного парубчака з їжачком. Якби.. Якби не зріс затурканим, занедбаним сиротою в запопадливій мужиџькій сім’і, то хтозна, щуо з нього вийшло б... Може, композитор, може, артист. Хтозна, хтозна...» [Гуменна 1998:25-26].

Неможливість фізичного бачення таланту не завадила Докії Гуменній описати його так, щоб читач зрозумів його велич і відчув гіркоту втрати того Божого дару через невдалий час та середовище, в якому він народився, зріс, але не розвинувся, не перейшов у щось велике, навіть величне й могутнє, а 
знівелювався й згас не отримавши належної оцінки та підтримки.

Таким чином, Докії Гуменній вдалося передати параметри тих явищ (почуттів, уявлень, відчуттів, здібностей...), які неможливо виміряти, оскільки не винайшло ще людство одиниць вимірів для них, не виробило стандартів та еталонів, але ж вони (ті явища) існують і впливають на життя людей, іноді вирішують їхні долі, прикрашають чи знебарвлюють світ, а відтак мусить людство на них зважати й рахуватися з їхньою наявністю в цьому світі і їхніми вимірами, нехай і поки що й своєрідними, такими, що ґрунтуються на відчуттях та почуттях, тобто символічними.

\section{БІБЛІОГРАФІЯ}

Віват 2013 - Віват Г. І. Наукова поезія XX століття: монографія / Ганна Віват - Одеса: ВМВ, 2013. - 240 с.

Гуменна 1998 - Гуменна Д. Діти Чумацького Шляху. Роман: У 4-х кн. / Докія Гуменна - К. : Український Центр духовної культури, 1998. - 576 с.

Костенко 1999 - Костенко Л. В. Маруся Чурай. / Ліна Костенко, Олексадр Олесь, Василь Симоненко, Василь Стус. - 2-ге вид. доп. - К. : Наук. думка, 1999. -272 c.

Сорока 2003 - Сорока П. Докія Гуменна. Літературний портрет: монографія / Петро Сорока - Тернопіль, 2003. - 495 с. 